\title{
To Whom It May Concern: Frustrated and Desperate Conan Moody
}

\section{THOUGHT IN PRISON I COULD GO TO SCHOOL OR GET A TRADE}

I will be in my mid-40s before I get released and this is my first time being incarcerated. When I got arrested, I knew beforehand that the outcome of the situation was that I was either going to go to jail or end up dead from a car crash. I decided to do it anyways because at that point in my life I wanted a change so bad that I was ready for the gamble. I had been selling drugs for a little over 25 years. I am not saying this to minimize the facts, but I sold everything but coke, speed, and heroin, for personal beliefs. I know that the government says that drugs are the problem, but in reality it is societywide problem, just look at the rat park revision studies (Gourbonov, 2019) that were done in the 2000's. Substance use/misuse has more to do with your environment than addictiveness. I am in support of the NDP's platform (NDP, 2019) that reflects some of the countries that have decriminalized or legalized drugs (Drug Policy Alliance, 2019) and that have had great results from it, results like a drop in most criminalized acts (ibid) contrary to the opinions of other countries or naysayers who said it would fail (NPR, 2019).

Although I was at a low point in my life and I was extremely tired of living the way I was, I was still contemplating how to move ahead. What I used to love doing had become the bane of my existence, rendering me depressed. I did not have the tools to do otherwise. I had tried to change my life, but with no success and I admittedly gave up on trying after a couple of failed attempts and since I did not have the will to change on my own. I needed something drastic to put me in a corner and not give me a choice. I figured that if I survived and just went to jail, it could be the catalyst I so desperately needed to turn my life around. I thought that in prison I would have better access to school and trade schools. I was just plain wrong. I did end up being able to go to school, but it took me 15 months to do so; all that because I had been arrested in Ontario and they did not want to transfer me back to Quebec.

They waitlisted me for programs even though I still had court in Montreal. 15 months later I finally got to where I am (Archambault Medium Security Institution). I was finally able to attend school, but as for trades there are very few and of the few that are available, they only include those 
that most people would not want to do, or not be able to market to have a decent quality of life, with jobs like custodian or laundry service. CORCAN will exploit you while you are serving time, yet they will not even hire you when you get out (CBC, 2017)!

We have some classes here for some jobs, but there is not much variety and when they are offered they are always full. The same is true for the school and access to the teachers is severely limited since they have so many students to deal with, which makes it very difficult to get help with your work. In fact, I have asked for a tutor, but I have been told that this type of support is not available. I also asked for an aptitude test so that I could find out what kind of job would be good for me, but I was informed that this service is not made available to prisoners.

I find that it is really hard to get the real help when you are a prisoner who wants to change their life. I was told that in jail you can learn any trade that you want, but based on my experience that is not the case. My sentence is almost up and I still have not finished school because taking a CSC mandated program took 15 months to complete as I had to be transported back and forth from Ontario to Quebec. All that did was disrupt my education (and still does thanks to the maintenance program). The program is a joke. It feels like a class for sociopaths to fine tune their skills. In fact, if you are honest, it is used against you, but if you lie you will be rewarded with a positive program evaluation. I have seen many people succeed with great results just end up back in prison after a couple of months, only to end up in higher security. The program also interferes with our ability to go to school and do classes for job skills since program is a priority.

I have asked multiple CSC decision makers for help on several occasions, but there is none that is available. All they do is tell me that I can talk to a social worker or psychologist and they cannot seem to do anything for me either.

\section{TIME IS MONEY BUT NOT FOR ME}

I owe $\$ 4,000$ in fines for minor stuff like walking my dog without a leash from over 6 years ago and $\$ 1,900$ in recent court fees, plus $\$ 2,500$ to my lawyer is past due and all that is not counting the $\$ 1,000$ to Hydro Quebec and the $\$ 600$ to welfare and $\$ 140$ or so to Fido for a phone bill. I tried to 
get all that sorted in advance of my release, but the people in charge of the fines do not care and just want money. I cannot even do extra time for it. Due to my current financial situation, I cannot even deal with Hydro and welfare or Fido.

Because the program took so much of my time and still does, it is interfering with my education that I so desperately need to have for my release and it is already going to be hard when I get out having to finish school. Especially since I will have to work and go to trade school at the same time as I complete community work. I fear for my sanity and you can ask anyone in rehab about doing too much at once when you are trying to change. It makes it damn near impossible because you need to focus on one thing at a time. I will be 44 and I do not have that many good years left, but I still want to do the best that I can for as long as I can, so my time is precious and I need to advance at a decent speed.

I feel that the Canadian penitentiary system is based on punishment and not rehabilitation. We get penalized for everything in here and get no positive rewards for doing well. For example, I go to school full-time, but it is only 4 days a week and we get around half our pay taken away via $30 \%$ food and accommodation deductions (Trounstine, 2018). If for some reason the school or class is closed we lose money. To compensate for that, I work another job on top of it all. So basically I work a total of six and a half days out of seven, yet I cannot get paid for more than five. When you calculate the prison expenses that we have to pay, we lose almost half (ibid) of what we earn!

Everything is expensive, I do not understand how we are supposed to put money aside for phone use (CSC, 2019) and community visits or private family visits, let alone purchase a TV or anything to do arts or create stuff for hobbies to be constructive and positive. More so, you have to save for when you get released, because the $\$ 80$ that CSC stipulates that you maintain in your savings account will not be enough to survive on, especially when you are like me, having lost everything and will not even have a bed to sleep on when you get out.

\section{RAISE THE PAY FOR PRISONERS}

The government needs to raise the pay for prisoners, not deduct more. You start out at $\$ 5.80$ a day for a full day of work and can eventually earn $\$ 6.35$, but reaching the highest pay grade, $\$ 6.90$, is practically impossible. 
The politics around obtaining this pay grade are so bad that if you do actually manage to get it, your fellow prisoners accuse you of being a rat or collaborating with the police! The food is also a major concern (Harris, 2017). I get that the food is not great, especially since we are in prison, but we should be able to make a little more money so we can afford to buy our own food and milk as well. It feels as if we are not allowed to eat healthy without saying goodbye to every other thing that costs money.

\section{WHERE IS THE REHABILITATION?}

What happened to workshops and hobbies, or classes such as yoga or Tai chi. Even the gymnasium is overcrowded and because the guards use it as well, it is almost impossible to go and use the equipment, since we only get access at night. We cannot even get books sent to us regularly to keep us mentally stimulated, instead of being mentally stagnant. Hell, you can get as many as you want in provincial, but in federal you are restricted from obtaining quality reading material. That makes no sense whatsoever, and on top of that we do not even have access to the internet or intranet. Even in the United States of America, some prisoners can access e-mail to communicate with their loved ones and friends in the community (Corrlinks, 2019).

With all the cuts that have taken place, they even recently stopped doing dental cleanings (CSC, 2015). Our teeth are important! We do not even have the option to pay for it (not that we really can afford it). I have also made two complaints that were not responded to for over a year: one for the loss of a cable for my CD player and the other for a lost health care card that was in my possessions, and I still have not gotten a response. Another concern is that we do not have shuttles for visits, which makes it very difficult for people like my parents to come visit as they are older and my dad has a leg problem. I am mentioning this because family visits are good for the mental health and stability of prisoners while serving their sentences.

Here in Canada, for some reason we are starting to go more towards the American way (Webster and Doob, 2015), like an easily influenced little brother. Are we not a world leader in human rights? I thought Canada was in support of treating people better and giving those who have made mistakes second chances? Am I just meant to fall in the cracks of society and become a homeless panhandler or an unhappy slave for minimum wage barely able to make ends meet? Should I just be dusted under a rug by ending back in 
jail? I want a real chance to be happy. I would rather die than go back to my former life. Going to prison has not been the catalyst to change my life. I will have very few other options left if I cannot get a better life.

\section{REFERENCES}

Burke, David (2017) "Job training program for prisoners stuck in the past says prison watchdog", $C B C$ News - January 27. Retrieved from https://www.cbc.ca/news/ canada/nova-scotia/prison-training-workforce-rehabilitation-prisoners-1.3953592

Correctional Services Canada [CSC] (2019) "Prisoner Phone Calls", Ottawa. Retrieved from Canada https://www.csc-scc.gc.ca/family/003004-0004-en.shtml

Correctional Services Canada [CSC] (2015) "The Dentist", Ottawa. Retrieved from https://www.csc-scc.gc.ca/csc-virtual-tour/15-eng.shtml

Corrlinks (2019) https://www.corrlinks.com/Login.aspx

Drug Policy Alliance (2019) "Drug Decriminalization in Portugal: Learning from a Health and Human-Centered Approach", New York. Retrieved from http://www. drugpolicy.org/sites/default/files/dpa-drug-decriminalization-portugal-healthhuman-centered-approach_0.pdf

Gorbounov, Sophia (2019) "Rat Park and the war on drugs", McGill Tribune November 26. Retrieved from https://www.mcgilltribune.com/sci-tech/rat-parkwar-drugs-261119/

Harris, Kathleen (2017) "\$5.41 per prisoner per day: bad food, small portions fueling prison tensions, federal watchdog finds", CBC News - January 27. Retrieved from https://www.cbc.ca/news/politics/correctional-investigator-zinger-report-1.4379823

New Democratic Party [NDP] of Canada (2019) Our Commitments, Ottawa. Retrieved from https://action.ndp.ca/page/-/2019/Q2/2019-06-19_Commitments-Doc_EN.pdf

NPR (2011) "Mixed Results for Portugal's Great Drug Experiment", January 20. Retrieved from https://www.npr.org/2011/01/20/133086356/Mixed-Results-ForPortugals-Great-Drug-Experiment

Trounstine, Jean (2018) "Fighting the fees that force prisoners to pay for their incarceration", Prison Legal News - November. Retrieved from https://www. prisonlegalnews.org/news/2018/nov/6/fighting-fees-force-prisoners-pay-theirincarceration/

Webster, Cheryl M. and Anthony N. Doob (2015) "US Punitiveness 'Canadian Style'? Cultural Values and Canadian Punishment Policy", Punishment \& Society, 17(3): 299-321.

\section{ABOUT THE AUTHOR}

Conan Moody is being held in a Canadian federal penitentiary. 